\title{
Information Literacy and the Art of Doing Research within the Context of an Engineering Technical Communication Class
}

\author{
Anne Parker \\ Design Engineering \\ University of Manitoba \\ Winnipeg, Manitoba R3T 5V6 \\ Anne_Parker@umanitoba.ca
}

\author{
Norma Godavari \\ Donald Craik Engineering Library \\ Faculty of Engineering \\ University of Manitoba R3T 5V6 \\ ngodava@cc.umanitoba.ca
}

\begin{abstract}
In this paper, we present some of the pedagogical outcomes of a study we undertook to determine whether research skills are valuable "soft skills" to have within an Engineering context, or whether they are merely "short-term competencies" as some would contend. We argue that engineering students (as future professionals) must develop two important - and confluent - skills: finding valid, complex technical information and translating it into a useful communication. As professionals, engineers must be able to find the information they need, assess it and apply it to their designs and to their communications. As students, they need to become acquainted with their professional discourse community, so we suggest that assigning a research paper in a field where applications and design exigencies are important is a worthwhile thing to do since this kind of research activity underpins students' future roles as professional engineers and promotes their lifelong learning. In the technical communication class offered in our school of Engineering, students learn how to engage in the systematic process of finding, selecting, organizing, distilling and presenting information, a process that enhances their comprehension of the subject, develops their critical thinking and introduces them to their discourse community.
\end{abstract}

\section{Introduction}

In this paper, we present some of the pedagogical outcomes and implications of a study we began in 2004 [1]. Since this is a unique attempt to integrate information literacy skills into an engineering course, this is still very much a work in progress. Our objective was to determine whether information literacy and the preparation of useful technical communications are indeed confluent skills. So, we began with two questions. First, is assigning a research paper - in a field where applications and design exigencies are important - a worthwhile thing to do and, secondly, within this context of an Engineering technical communication class, are research skills valuable skills for our students to acquire or are they, as Feinberg and King suggest, merely "short-term competencies" [2, pp. 26-27]?

To answer some of these questions, we first administered a survey to the undergraduate students enrolled in the technical communication class, as Williams, Blowers and Goldberg suggest [3]. The students' responses helped us to determine the students' information literacy knowledge and needs as well as their initial information-seeking habits [3, p. 4]. For example, in response to a question on their favorite search engine, over $85 \%$ said they "Googled" most things. Certainly, as a source of general information, this search engine is exceptional. However, as Tenopir and King assert, most Engineering students and professionals - both in their work and in their communications - need to be able to find the specialized technical information they need, assess it and apply it [4]. And doing so demands a much more sophisticated search for information than "Googling" will allow.

Consequently, the librarian and the technical communication professor together introduced a series of tutorials into the course curriculum that would teach information literacy skills. Part of that process entailed assessing the overall balance of information sources and verifying the annotated references in an early and then in a later draft of the students' reports. Building on McCord and Nerz's work [5], the librarian connected her evaluation criteria to information literacy standards developed by the Association of College and Research Libraries [6] as well as both the American and the 
Canadian Engineering accreditation criteria (ABET and CEAB respectively). In this way, what the students are learning in these tutorials conforms to accreditation requirements at the same time as the classes promote lifelong learning.

However, each country's accreditation criteria do not always stress the same things. American engineering libraries, for example, are fortunate to have the revised ABET criteria that focus on "outcomes assessment," as noted by Clemens, Gibbs and Shelton [7, p. 1]. As well, there is a growing body of literature that relates the ABET criteria to information literacy. In Canada, on the other hand, the accreditation criteria are less prescriptive and do not specifically refer to "lifelong learning skills," which are stressed by Tenopir and King [4, p. 182]. Yet, in light of the ACRL definition of "information literacy," we can nonetheless identify criteria that relate the ACRL standards to those of the CEAB.

Thus, engineering students in this technical communication class begin to develop the requisite "soft skills" - including research skills - that are increasingly important within an Engineering context; that is, students learn how to engage in the systematic process of finding, selecting, organizing, distilling and presenting information, a process that enhances their comprehension of the subject, develops their critical thinking and introduces them to their discourse community through their introduction to controlled vocabularies.

\section{The Technical Communication Class in Engineering}

The technical communication course that is offered in the Faculty of Engineering at the University of Manitoba is a second-year, mandatory course that is also team-based. The course covers such topics as project management, team management, oral presentations, document design and textual illustrations, and covers the genres of engineering communication. As shown in Table 1 , the course itself is divided into a series of tutorials that focus on three elements related to these topics: the technical and communication elements, and the team elements, all of which reflect the problem-solving nature of Engineering $[8 ; 9 ; 10]$ as well as the importance of communication and collaboration to the discipline [11]. Eventually, these elements will lead to the finished product, the necessary outcome of the collaboration. In a technical course, this might be a product or a design; in a communication course, this will be the final report itself.

Table 1. The focus of the tutorials

\begin{tabular}{|l|l|l|}
\hline $\begin{array}{l}\text { Technical } \\
\text { Elements }\end{array}$ & $\begin{array}{l}\text { Communication } \\
\text { Elements }\end{array}$ & $\begin{array}{l}\text { Team } \\
\text { Elements }\end{array}$ \\
\hline $\begin{array}{l}\text { Technical } \\
\text { Problem }\end{array}$ & Purpose Definition & $\begin{array}{l}\text { Team } \\
\text { Planning }\end{array}$ \\
\hline $\begin{array}{l}\text { Technical } \\
\text { Criteria }\end{array}$ & $\begin{array}{l}\text { Organization \& } \\
\text { Format }\end{array}$ & $\begin{array}{l}\text { Project } \\
\text { Planning }\end{array}$ \\
\hline Research & $\begin{array}{l}\text { Issues of Style \& } \\
\text { Revision }\end{array}$ & $\begin{array}{l}\text { Monitor \& } \\
\text { Reflect }\end{array}$ \\
\hline
\end{tabular}

The technical elements include all the task needs associated with the teams' engineering-related project, such as defining the technical problem to be addressed as well as the research to be done, while the communication elements include the procedural needs, such as those things that must be in place in order for the team to reach that outcome. For example, if the team is to complete the task, not only must issues of style and revision (such as the strategies the team will use to review their work), but also issues of organization and format must all be determined. Finally, because these relate to the team's interactions as well as the social and emotional needs of the individual team members, it is the team elements that will promote team interactions, team planning and project planning.

And the assignments reflect these various elements. Indeed, the assignments have been designed to help students experience and practice all these elements, learn the engineering genres, and develop their communication and teaming skills, as outlined by ABET and CEAB [12]. However, because many students often choose to take the technical communication course later in their program, or even postpone taking it altogether (until they discover that they must complete the course in order to graduate), the class is a heterogeneous one in that students will be at different stages of their programs, and 
their concomitant level of experience will also vary widely - making an industry-based assignment hard for many of them to do. Therefore, the final written report that each team submits at the end of the course is a research paper, one that looks at a particular engineering technology and evaluates it.

Nevertheless, even though some would argue that a research paper is more an academic than an engineering genre and would even go so far (as Irish does) to suggest that research papers are really just exercises in "knowledge assembly" [13, p. 75], the report submitted by each team at the end of the semester still represents the culmination of their work. Assignments are "staged," to use Brent's word, and it is this staging of the assignments that Brent argues is so crucial to effective research papers and to team-based work [14, p. 258]. For example, early in the course, teams prepare a team proposal in which they propose to look at their chosen topics; later, about midway through the semester, they give a progress report on their project. Both the team proposal and the progress reports must include the three elements; in this way, teams demonstrate that they are in fact addressing a technical problem at the same time as they are carefully delineating the team elements that must be in place if they are to successfully collaborate. Finally, the team's communication procedures must also be clearly delineated.

So, while some would argue that industry-based assignments are more "relevant," we would argue that a research-based assignment is actually quite valuable in this context for the following reasons. On the one hand, students do not simply narrate what the technology looks like or what it does; rather, they must learn all about the technology. Doing so enables them to evaluate it; that is, they must be able to evaluate that technology by defining the technical issues and by developing criteria. They must look at applications, design exigencies, the usefulness of the technology they are writing about. Thus, by learning about the team elements and practicing them in their work, they learn to analyze the technical elements within the framework of both the communication elements and the team elements.

On the other hand, the research-based report is surprisingly flexible. While they do indeed research what has already been done, they also have the chance to learn "new concepts," to "teach themselves" and to "apply information to new (and unfamiliar) situations" [15, p. 5822]. In this important sense, then, we are helping them to become "lifelong learners" [3; 15]. And part of that preparation includes being able to find the specialized technical information they need, assess it and apply it, as Tenopir and King [4] and Bodi [16] argue. Thus, our starting point is a relatively simple one: students cannot create the design or determine its applications - let alone write about them - if they have little or no background in the field. Put another way, "knowing which resource is best for which type of question necessitates being information literate" [17, p. 247].

\section{Information Literacy Tutorials in the Technical Communication Class}

Over the years, these tutorials have evolved, from mere one hour "orientations" to integral parts of the technical communication class. Now, the librarian is involved in the grading of assignments like the team proposal and the final written report; specifically, following the Feldmanns' model [18, p. S2E-2], the instructor evaluates the report's content and the librarian assesses the search process. Overall, the objectives of these information literacy tutorials are to search, source, assess and cite materials in the most efficient way, as shown in Table 2. Each of the tutorials contains elements of all four objectives, but with varying degrees of emphasis.

Table 2. Information literacy objectives

\begin{tabular}{|l|l|l|l|}
\hline \multicolumn{1}{|c|}{ Search } & Sources & \multicolumn{1}{|c|}{ Assess } & \multicolumn{1}{c|}{ Cite } \\
\hline $\begin{array}{l}\text { Databases } \\
\text { AND } \\
\text { Search } \\
\text { Engines } \\
\text { [learn } \\
\text { thoroughly] }\end{array}$ & $\begin{array}{l}\text { Assess } \\
\text { Topic } \\
\text { Needs }\end{array}$ & $\begin{array}{l}\text { Critical } \\
\text { Thinking }\end{array}$ & $\begin{array}{l}\text { Select \& } \\
\text { Learn } \\
\text { Method } \\
\text { [APA or } \\
\text { IEEE] }\end{array}$ \\
\hline $\begin{array}{l}\text { Boolean } \\
\text { Logic }\end{array}$ & $\begin{array}{l}\text { Related } \\
\text { Databases }\end{array}$ & $\begin{array}{l}\text { Evaluation } \\
\text { of Sources }\end{array}$ & $\begin{array}{l}\text { Practice \& } \\
\text { Ask! }\end{array}$ \\
\hline $\begin{array}{l}\text { Controlled } \\
\text { Vocabularies }\end{array}$ & $\begin{array}{l}\text { Hidden } \\
\text { Web }\end{array}$ & $\begin{array}{l}\text { Relate } \\
\text { Source to } \\
\text { Topic }\end{array}$ & \\
\hline $\begin{array}{l}\text { Focus \& } \\
\text { Refine }\end{array}$ & $\begin{array}{l}\text { Patents, } \\
\text { Standards, } \\
\text { Theses }\end{array}$ & & \\
\hline
\end{tabular}


As Nerz and Weiner have emphasized, one point for integrating information literacy "instruction occurs in the context of an assignment" [15, p. 5824] - which is what we have designed. Because the course is a mandatory one for our Engineering students, at the very least they all receive some information literacy basics. Even more important, as mentioned earlier, the course, the assignments and these information literacy basics are all tied to $\mathrm{CEAB}, \mathrm{ABET}$ and ACRL criteria, as shown in a modified version of the librarian's marking rubric (Table 3).

\section{Table 3. Integration of information literacy}

\begin{tabular}{|c|c|}
\hline $\begin{array}{l}\text { CEAB, } \\
\text { ACRL \& } \\
\text { ABET } \\
\text { Outcome }\end{array}$ & SKILL SET \\
\hline $\begin{array}{l}\text { CEAB, 2.1.1, } \\
2.1 .3 \\
\text { ACRL, } 2 \\
\text { ABET, 3.c, 3.e, } \\
3 \mathrm{k}\end{array}$ & $\begin{array}{l}\text { Finding Information [Search Strategy] } \\
\text { topic/problem clearly } \\
\text { articulated } \\
\text { searches demonstrate a clear } \\
\text { understanding of the topic } \\
\text { - lear search strategy } \\
\text { - Use of controlled } \\
\text { vocabularies }\end{array}$ \\
\hline $\begin{array}{l}\text { CEAB, 2.1.1., } \\
2.1 .3 \\
\text { ARCL, 1.3.a } \\
\text { ABET, 3.h, } 3.1\end{array}$ & $\begin{array}{ll}\text { Locating Information [Search } \\
\text { Sources] } \\
\text { - } \\
\text { - } \\
\text { semonstrated quality } \\
\text { variety of databases \& search } \\
\text { engines used } \\
\text { use of library search tools (as } \\
\text { opposed to just search } \\
\text { engines) }\end{array}$ \\
\hline $\begin{array}{l}\text { CEAB, 2.1.5 } \\
\text { ACRL, 5 } \\
\text { ABET, 3.b, 3.f, } \\
\text { 3.g }\end{array}$ & $\begin{array}{l}\text { Synthesizing Information } \\
\text { [Annotations \& Relevancy to } \\
\text { Topic] } \\
\text { team understanding of the } \\
\text { information } \\
\text { - } \begin{array}{l}\text { ability of summarize the } \\
\text { information } \\
\text { - } \\
\text { relevance of the sources to the } \\
\text { - report } \\
\text { evidence of plagiarism }\end{array}\end{array}$ \\
\hline $\begin{array}{l}\text { CEAB, 2.1.1 } \\
\text { ACRL, 5.3.1 } \\
\text { ABET, 3.g, 3.i }\end{array}$ & $\begin{array}{c}\text { Presenting Information [Citation Style] } \\
\text { IEEE or APA style used } \\
\text { accuracy of the style used }\end{array}$ \\
\hline
\end{tabular}

In order to focus on outcomes assessment, as noted by Clemens, Gibbs and Shelton [7, p.1], the librarian has developed a set of three tools which, taken together, inform and assess student research. They include: a rubric (as shown in Table 3) based on that developed by Nerz and McCord but modified to better reflect the objectives of this technical communication class; the search sheets that students fill out and hand in with their team proposals and their final written reports; and the marking sheets, which summarize the librarian's assessment of the team's research in the team proposal and, later, in the final written report. Students receive copies of each of these sheets in the first tutorial.

The rubric includes the five sections that relate to the various research areas and reflect the course itself. The search sheets - one for the team's proposal early in the semester and one for their final written report at the end of the course - reveal how students have gone about researching their topics and, together with the marking sheets (the third tool), illustrate how research is really a process. These marking sheets allow the librarian to offer suggestions on the search and on the topic; for example, here she might suggest other databases or sources to try or faculty to talk to. Finally, throughout this process, teams and individual students make appointments with the librarian and receive oneon-one help in their search process, or they will email her with questions and concerns.

Clearly, one of the advantages of offering these tutorials has been the enhanced profile of the librarian and of what the library itself has to offer. But there are also disadvantages that, every year, need to be addressed. For instance, initially, students were overwhelmed by the sheer number of handouts. Also, too much information, given within a short time frame, only complicated things. So, together, the professor and the librarian restructured the course outline and changed when the different tutorials would be offered. For example, the initial class was fairly short, and could stand alone early in the course while later research tutorials, such as those dealing with the databases, needed more time; these were placed closer to the course tutorials dealing with team assignments like the team proposal.

Other issues arose as well. Since the course is multi-sectioned, the librarian tracked the results from each of the sections. There were some marked differences. For example, the professor attended all research tutorials offered 
to her students, and her teams did better overall than the sections where the instructors did not attend regularly. Indeed, this result would confirm Kerry Smith's assertion of the need for professors to be present during these sessions since that presence adds to the credibility of the material and, at the same time, increases students' attention and focus [19, pp. 47-48].

\section{Implications and Pedagogical Outcomes}

Since we began our study, we have noticed that we need to pay more attention to ubiquitous issues like plagiarism, now more problematic than ever with the availability of online sources. In a field like Engineering, where ethics govern the profession, this is an issue of real significance. Although plagiarism is something to be discussed and dealt with at a faculty level, it is also a timely topic that information literacy tutorials can cover in depth. As a result, the librarian spends almost one entire class on this topic. So, too, with the issue of "Google," the search engine of choice for most students, who need to hear about how to use it appropriately and effectively; we now have another entire class to deal with this topic. Finally, until and unless information literacy becomes more curriculum-based, as Nerz and Weiner suggest [15], what the students in the technical communication course acquire might well be the "short-term competencies" that Feinberg and King point out [2, pp. 26-27].

Having said this, however, there are some pedagogical outcomes that bode well for the introduction of information literacy within a faculty of Engineering. Now that many schools are integrating communication into their technical courses, such as the capstone courses, the opportunity is there to also introduce information literacy, as we are doing in our school as early as the fall of 2007. Additionally, we are hoping to introduce a graduate course in technical communication that will help our graduate students to cope with the sundry writing and oral demands of graduate school. Here, too, information literacy can be a valuable and integral part of the curriculum.

Finally, these skills have been increasingly recognized as important to the engineering profession and not just engineering education $[17 ; 20]$. It is information literacy that helps engineers access recent information on technology, synthesize it and evaluate it. As
Mosley states, “in today's fast-paced, highly competitive world of technology, the need for rapid, accurate information is increasingly important" [21, p. 51]. Similarly, Tenopir and King's study confirms that "receiving and using information requires substantial amounts" of an engineer's time, not to mention the time required using "information seeking tools such as technologies and library resources" [4, p. 7]. In this important sense, then, understanding how engineers access and use their information is a critical first step in preparing our students to make their engineering communications effective [4, p.12].

\section{Conclusion}

If we define information literacy as the systematic process of finding, selecting, organizing, distilling and presenting information in a way that improves a student's comprehension in a specific area of interest, then library research introduces students to the necessary engineering background by introducing them to critical thinking and to engineering "lingo"; that is, to the terms and precepts of their field and to their professional discourse community. Consequently, the research paper can become more than mere "knowledge assembly" [13, p. 75] and information literacy skills can become more than mere "short-term competencies" [2, p. 26-27]. Indeed, in Bodi's words, "a research paper has the potential of engaging undergraduates in the process of inquiry to pursue knowledge and to think critically" [16, p. 109]. Nagelhout further argues that technical writing assignments must encourage students to think "critically and reflectively" about their research practices if they are to evaluate "the overwhelming amounts of information available to them" [22, p. 285]. This is something the research paper can do - if information literacy is an integral part of the communications course.

In the final analysis, accreditation boards are now recognizing the importance of the "soft skills" to engineering education and to the engineering profession. This kind of recognition would seem to confirm our assertion that acquiring both information literacy skills as well as communication skills is - or should be critical to engineering education. At least in the case of the technical communication course offered at the University of Manitoba, they are becoming so. 


\section{References.}

[1] Versions of this paper have been presented at the CATTW (Canadian Association of Teachers of Technical Writing) conference in May, 2004, and at the ASEE conference in June, 2006.

[2] R. Feinberg and C. King, "Short-term Library Skills Competencies: Arguing for the Achievable," College and Research Libraries, Jan. 1988, pp. 24-28.

[3] B. Williams, P. Blowers and J. Goldberg, "Integrating Information Literacy Skills into Engineering Courses to Produce Lifelong Learners," in ASEE Annual Conference Proceedings 2004, pp. 7719-7729.

[4] C. Tenopir and D.W. King, Communication Patterns of Engineers, Piscataway, NJ, IEEE Press, 2004.

[5] M. McCord and H. Nerz, Using Information Literacy Standards to Meet ABET Accreditation Outcomes [Online]. Retrieved August 6, 2005, from

http:/eld.lib.ucdavis.edu/conf/03/mccord.ppt

[6] Association of College and Research Libraries (ACRL), Information Literacy Standards for Science and Engineering Technology [Online]. Retrieved June 11, 2007 from

http://www.ala.org/ala/acrl/acrlstandards/infolits citech.htm

[7] L. Clemens, P. Gibbs and M. Shelton, "Information Literacy Competency and its Integration into the Engineering Curriculum," in Proceedings of the 2002 American Society for Engineering Education Zone 1 Conference, 2002.

[8] A. Parker, Handbook for Technical Communication, Boston, MA, Pearson Custom Publishing, 2005.

[9] K.A. Smith (in collaboration with P.K. Imbrie), Teamwork and Project Management, $3^{\text {rd }}$ Edition, Boston, MA, McGraw Hill Higher Education, 2007.

[10] A.R. Edie, R.D. Jenison, L.L. Northup and S.K. Mikelson, Engineering Fundamentals \&
Problem Solving, $5^{\text {th }}$ Edition, Boston, MA, McGraw Hill Higher Education, 2008.

[11] Canadian Council of Professional Engineers (CCPE), Report of the CCPE Accreditation Review Committee, November 1996.

[12] ABET's 3.g., and CEAB's 2.1.5. and 2.2.8. See ABET Engineering Accreditation Commission, 2006-2007 Criteria for Accrediting Engineering Programs [Online]. Retrieved May 30, 2006 from http:www.abet.org/Linked Documents-UPDATE/

Criteria and PP/E001 06-07 EAC Criteria 5-25-0606.pdf. See also Canadian Council of Professional Engineers, Accreditation Criteria and Procedures, 2005 [Online]. Retrieved March 9, 2006 from http://www.ccpe.ca/e/files/report_ceab.pdf

[13] Irish, R.K., "Just-in-time Teaching for Written and Oral Communication: An Engineering Paradigm," in Proceedings of the $12^{\text {th }}$ Canadian Conference on Engineering Education, ASEE 2001, pp. 74-81.

[14] D. Brent, "Reinventing WAC (Again): The First Year Seminar and Academic Literacy," College Communication and Composition, v.57, no.2, pp. 253-276.

[15] H. Nerz and S.T. Weiner, "Information Competencies: A Strategic Approach," in ASEE Annual Conference Proceedings, 2001, pp. 5821-5831.

[16] S. Bodi., "How Do We Bridge the Gap between What We Teach and What They Do? Some Thoughts on the Place of Questions in the Process of Research," The Journal of Academic Librarianship, May 2002, pp. 109-114.

[17] J.B. Napp., "Survey of Library Services at Engineering News Record's Top 500 Design Firms: Implications for Engineering Education," Journal of Engineering Education, July 2004, pp. 247-252.

[18] L. Feldmann and J. Feldmann, "Developing Information Literacy Skills in Freshman Engineering Technology Students," in Proceedings, Frontiers in Education Conference, v.2, 2000, pp. S2E-1-S2E-4.

[19] K.J. Smith, "Professor Attendance as a Factor in Perceived Library Instruction Effectiveness: An Exploratory Study," Reference Services Review, v. 30, no.1, 2002, pp. 43-48. 
[20] R.J. Rodrigues, "Industry Expectations of the New Engineer," Science and Technology Libraries, Vol. 19, No. 3/4 2001, pp. 179-188.

[21] P.A. Mosley, "Engineers and Librarians: How Do They Interact?" Science and Technology Libraries, Vol. 15, No. 1 1995, pp. 51-61.

[22] E. Nagelhout, "Pre-Professional Practices in the Technical Writing Classroom: Promoting Multiple Literacies through Research," Technical Communication Quarterly, Vol. 8, No. 3 1999, pp. 285-299. 